\title{
Hubungan Antara Pembelajaran Penjas Dengan Perilaku Sosial Siswa (Studi Deskriptif di SMA Negeri 10 Kota Bandung)
}

\author{
Anna Mariam Sofiarini ${ }^{1}$ \\ Universitas Pendidikan Indonesia
}

\begin{abstract}
Abstrak
Penelitian ini dilatarbelakangi oleh perilaku sosial siswa yang baik individu maupun beregu masih ada yang belum dapat menyesuaikan diri dengan lingkungannya dalam pembelajaran pendidikan jasmani (penjas). Tujuan penelitian ini adalah untuk mengetahui perilaku sosial dalam pembelajaran penjas dan memperoleh gambaran mengenai hubungan pembelajaran penjas dengan perilaku sosial siswa. Metode penelitian yang digunakan adalah metode penelitian deskriptif pada siswa kelas X di SMAN 10 Bandung yang berjumlah 300 siswa, dan untuk sampel yang diambil 20\% dari populasi yaitu 60 siswa. Instrumen yang digunakan adalah angket atau kuisioner dan dokumentasi penelitian. Sebelum mengetahui hasil dari penelitiannya diuji angket terlebih dahulu, butir pernyataan yang dibuat sebanyak 50, kemudian setelah diuji angket terdapat pernyataan yang tidak valid sehingga pernyataan yang valid sebanyak 47 butir. Hasil dari penelitian ini didapat jumlah 10.120 dengan rata-rata 168.07 dan simpangan baku 15,04 kemudian untuk uji normalitas didapat Lo 0,48 dengan kesimpulan normal karena Lo < Lt. Hasil uji signifikan koefisien korelasi untuk penelitian ini didapat $r$ 0,86 dengan interpretasi korelasi sangat kuat, sedangkan $t_{\text {hitung }} 12,8>t_{\text {tabel }} 2,00$. Maka keterangan dari hasil ini menunjukkan adanya hubungan yang signifikan antara pembelajaran penjas dengan perilaku sosial siswa.
\end{abstract}

Kata Kunci: Pembelajaran Pendidikan Jasmani, Perilaku Sosial Siswa 


\section{PENDAHULUAN}

Pada hakikatnya manusia adalah makhluk hidup yang diciptakan oleh Allah swt dengan dikaruniai akal untuk berfikir serta sebagai mahluk sosial. Dengan akal tersebut manusia melaksanakan kehidupannya tidak akan lepas dari pendidikan, karena pendidikan berfungsi meningkatkan kualitas sumber daya manusia. Pendidikan adalah usaha untuk mewujudkan suasana belajar dalam proses pembelajaran agar siswa aktif mengembangkan potensi dirinya. Seperti dalam proses belajar dikemukakan bahwa siswa yang mulanya tidak tahu akan menjadi tahu, dari awalnya yang tidak bisa menjadi bisa, dengan begitu akan tercipta dalam suatu pendidikan. Pendidikan yang ditempuh oleh semua manusia , baik itu dari dalam (keluarga) maupun dari luar (sekolah, tempat les, media sosial,dll). Pendidikan di sekolah memberikan banyak pengetahuan mengenai pembelajaran, sikap, keterampilan, dll. Dalam kamus besar bahasa indonesia pendidikan berasal dari kata didik, lalu kata ini mendapat awalan kata -me sehingga menjadi mendidik artinya memelihara dan memberi latihan. Dalam memelihara dan memberi latihan diperlukan adanya ajaran, tuntutan dan pimpinan mengenai akhlak dan kecerdasan pikiran.

Pendidikan jasmani dilaksanakan melalui aktivitas fisik yang bertujuan mendidik siswa secara jasmani dengan materi pembelajaran aktivitas jasmani yang dilakukan dengan permainan menyerupai olahraga. Dengan permainan tersebut dapat mewujudkan tujuan dari pendidikan melalui pembelajaran pendidikan jasmani yang muara akhir dari pembelajaran tersebut ialah siswa yang terdidik secara utuh (fisikal, mental,sosial, emosional).Pendidikan jasmani mempunyai banyak ciri unik yang dapat dilihatnya selain dari proses pembelajaran, proses pengajaran, sarana dan prasana serta alat atau media yang digunakannya. Pendidikan jasmani dituntut untuk memberikan pembelajaran sesuai dengan yang ada dalam kurikulum juga aturan yang sudah baku serta panduan atau petunjuk yang telah dirancang sebelumnya oleh pengajar tersebut namun didalam proses belajar mengajarnya dibuat sedemikian rupa untuk menimbulkan susasana yang selalu menggembirakan, menyenangkan, tidak membosankan, dan menarik. Sehingga setiap siswa yang mengikutinya secara tidak langsung dan tidak sadar akan apa yang telah dipelajarinya mempunyai banyak manfaat bagi peserta didiknya atau siswanya itu sendiri. Dengan demikian pendidikan jasmani dalam pembelajarannya memiliki beberapa aspek penting yang secara tidak langsung berjalan bersamaan 
dalam proses pembelajaran dapat dimiliki setiap peserta didik atau siswanya. Aspek tersebut diantaranya yaitu, pertama adalah aspek psikomotor atau yang sering dikenal dengan aspek keterampilan yang biasanya bertumpu pada perkembangan kemampuan biologis organ tubuh/fisik yang dapat dilihat secara langsung dari tehnik atau penguasaan gerak siswa tersebut dalam mempelajari penjas. Kemudian aspek kognitif atau aspek pengetahuan yang mencakup fakta-fakta, konsep, penalaran, pemahaman, hafalan dan kemampuan memecahkan masalah yang dapat siswa terapkan atau ketahui mengenai sejarah ,tata cara, teori, atau apapun yang berhubungan dengan penjas. Dan aspek afektif atau aspek sikap yang mencakup sifat-sifat psikologi yang menjadi unsur kepribadian yang kokoh, yang dapat mencerminkan sikap seorang siswa didalam suatu kegiatan pembelajaran penjas. Tidak hanya tentang sikap sebagai kesiapan berbuat yang perlu dikembangkan, tetapi yang lebih penting adalah konsep diri dalam komponen kepribadian lainnya.

Pendidikan jasmani merupakan 'alat' pendidikan, atau yang disebut sebagai salah satu media pendidikan yang dalam prosesnya bisa mewujudkan tujuan dari pendidikan sekaligus pembudayaan. Proses ini merupakan sebuah syarat yang memungkinkan manusia mampu terus mempertahankan kelangsungan hidupnya sebagai manusia. Namun terkadang timbul permasalahan dalam pembelajaran pendidikan jasmani menyangkut dalam aspek afektif yaitu mengenai perilaku sosial siswa. Masalah perilaku sosial siswa yang timbul pada anak sekolah menengah atas dapat mempengaruhi kepribadian setiap individunya. Seperti tujuan dari proses penjas tidak hanya pada aspek psikomotor saja, tetapi mencakup aspek kognitif dan afektif. Disamping aspek kognitif dan psikomotor, aspek afektif juga harus dimiliki siswa karena sangat erat hubungannya dengan perilaku siswa. Perilaku siswa saat ini baik individu maupun beregu masih ada yang belum dapat menyesuaikan diri dengan lingkungannya, memilih-milih teman dan kurangnya bersosialisasi dengan teman lainnya disekolah. Perilaku Sosial Siswa sangat penting adanya pada setiap siswa terutama pada siswa sekolah menengah atas dikarenakan siswa memasuki fase remaja (15-18 tahun) dimana pada fase ini identik dengan pencarian jati diri dan timbul dorongan untuk mencari sesuatu yang dipandang bernilai dan pantas dijunjung tinggi. Pada fase remaja inilah masih banyak siswa yang dapat terpengaruhi oleh lingkungan yang terutama oleh teman sebayanya sehingga perilaku sosial siswa sangat erat 
kaitannya dengan pembelajaran penjas. Karena dalam pembelajaran penjas dapat dilihat seberapa besar perilaku sosial berperan penting bagi siswa. Seperti pada saat pembelajaran penjas berlangsung siswa dibutuhkan kerjasama untuk melakukan suatu kegiatan yang dilakukan secara berkelompok, dengan demikian siswa secara tidak langsung harus ketergantungan dengan kelompoknya agar mendapatkan hasil yang maksimal. Dari kerjasama tersebut dapat dilihat perilaku sosial yang ada di setiap individunya.

Seperti penjelasan mengenai perilaku sosial menurut Krech, Crutchfield dan Ballachey (1982) dalam Abidin (2015, hlm. 31)Perilaku sosial seseorang itu tampak dalam pola respons antar orang yang dinyatakan dengan hubungan timbal balik antar pribadi.Dalam pola respons antar orang terdapat beberapa kecenderungan perilaku menurut Krech, Crutchchfield dan Ballachey (1982) dalam Oom Rohmah (2010, hlm. 36) ialah kecenderungan perilaku pearan yang meliputi sifat pemberani dan pengecut, sifat berkuasa dan patuh, sifat inisiatif sosial dan pasif, sifat mandiri dan ketergantungan. Kemudia kecenderungan perilaku dlm hubungan sosial meliputi dapat menerima dan ditolah oleh seseorang, suka bergaul dan tidak bergaul, ramah dan tidak ramah, simpatik dan tidak simpatik. Serta kecenderungan perilaku ekspresif meliputi suka bersaing dan kerjasama, agresif dan tidak agresif, kalem, dan uka pamer. Manusia pada hakikatnya merupakan makhluk hidup, disamping itu juga merupakan makhluk sosial yang memiliki keikhlasan masing-masing individu tidak bisa lepas dari lingkungan sosialnya. Dalam upaya memenuhi kebutuhannya, manusia tidak dapat melakukannya sendiri, tetapi membutuhkan bantuan orang lain. Istilah lain kelangsungan hidup manusia terlaksana dengan saling membutuhkan, saling melengkapi dan saling ketergantungan satu sama lain. Selain itu manusia juga merupakan makhluk sosial yang tidak terlepas dari interaksi-interaksi dari lingkungan sekeliling yang saling mempengaruhi satu sama lainnya yang mana manusia bergantung dengan bantuan orang lain dan tidak dapat hidup secara sendiri. Sesuai dengan proses belajar mengajar bahwa rangkaian interaksi antara siswa dan guru untuk mencapai tujuan melalui berbagai proses dapat mewujudkan suatu perubahan baik pribadi maupun perilakunya.Perilaku itu ditunjukkan dengan perasaan, tindakan, keyakinan, dan rasa hormat terhadap orang lain. Perilaku sosial seseorang merupakan sifat relatif untuk menanggapi orang lain dengan cara-cara yang berbeda-beda. Misalnya dalam melakukan kerja sama, 
ada orang yang melakukannya dengan sabar dan selalu mementingkan kepentingan bersama dibandingkan dengan kepentingan pribadinya sendiri. Sementara di pihak lain, ada orang yang bermalas-malasan, tidak sabaran dan hanya ingin mendapatkan keuntungan tersendiri. Perilaku sosial yang dilakukan siswa disertai dengan adanya hubungan antar individu, baik antara siswa dengan siswa, siswa dengan guru, atau hubungan dengan masyarakat sekolah lain. Dalam hubungan antar individu tersebut siswa akan menggembangkan pola respon tertentu dalam bentuk perilaku hubungan antar siswa dengan kehidupan sekolah yang dimana siswa itu sendiri akan memiliki beragam keunikan perilaku sosial yang dipengaruhi oleh lingkungan sekitarnya. Dalam menggembangkan pola respons antar individu terebut siswa dapat menunjukkannya melalui pembelajaran pendiikan jasmani. Siswa tanpa sadar pada saat melakukannya sudah memiliki aspek kognitif, afektif, dan psikomotor yang menjadi hasil dari pembelajaran. Menurut Loree (1970, hlm. 1330) dalam Makmun (2007, hlm. 166) selain itu pada saat proses belajar berlangsung siswa sudah mempunyai input( motivasi, bakat, kesiapan, dll) kemudian sarana(guru, metode, alat, bahan ajar, dll) serta lingkungan(budaya, fisik, lingkungan sekitar). Dari semua faktor tersebut dapat terlaksana proses belajar mengajar dalam pendidikan jasmani yang bisa mempengaruhi atau berpengaruh pada perilaku sosial siswa.

\section{METODE}

Dalam penelitian ini proses pemecahan masalah yang akan dilakukan melalui metode deskriptif, Menurut Sugiyono (2013, hlm. 147) bahwa penelitian dekriptif adalah penelitian yang digunakan untuk menganalisis data dengan cara mendeskripsikan atau menggambarkan data yang telah terkumpul sebagaimana adanya tanpa bermaksud membuat kesimpulan yang berlaku untuk umum atau generalisasi. Berdasarkan pendapat di atas dapat disimpulkan bahwa metode deskriptif yaitu suatu cara penelitian yang mengarah pada pemecahan masalah yang ada pada masa sekarang dengan cara mengambil data dengan berbentuk deskripsi. Dalam setiap penelitian akan ditemukan variabel yang menjadi masalah dalam penelitian.

\section{Populasi dan Sampel}

Pada penelitian ini peneliti mengambil populasi sebanyak 300siswa yang termasuk dalam seluruh kelas $\mathrm{X}$ di SMAN 10 kota bandung. 
Kemudian dari 300siswa peneliti mengambil $20 \%$ sesuai dengan pendapat Arikunto (2002, hlm. 112) bahwa untuk sekedar ancer-ancer maka apabila subyeknya kurang dari 100 lebih baik diambil semua sehingga penelitiannya merupakan penelitin populasi, selanjutnya jika jumlah subyeknya besar, dapat di ambil 10-15\% atau 20-25\% atau lebih , maka didapat sampel siswa sebanyak 60siswa yang diambil secara acak.

\section{Desain dan Prosedur}

Desain dalam penelitian ini mengenai hubungan maka ada dua variabel didalamnya, variabel bebas dinyatakan dengan simbol $\mathrm{X}$, dan variabel terikat dinyatakan dengan simbol Y. Variabel bebas tersebut adalah pembelajaran penjas, sedangkan variabel terikat adalah perilaku sosial siswa. Dengan menyebarkan angket menjadi instrumen dalam penelitian ini, peneliti melakukan penelitian sebanyak $2 \mathrm{x}$ yang pertama menyebarkan uji angket dan mengobservasi pembelajaran penjas kemudian yang kedua menyebarkan angket penelitian dan mengobservasi kembali mengenai pembelajaran penjas. Observasi yang dilakukan untuk mendapatkan dokumentasi mengenai pembelajaran pendidikan jasmani.

\section{HASIL}

Dalam angket penelitian terdapat 43 butir pernyataan yang valid, dari 50 butir pernyataan yang di jadikan uji coba angket maka 7 butir pernyataan yang tidak valid dibuang karena dari setiap buti pernyataan yang tidak valid sudah ada yang mewakilkan. Dengan demikian hasil dari angket penelitian memiliki jumlah skor (10.120) kemudian ratarata sebesar $(168,07)$ dan simpangan baku $(15,04)$. Untuk uji normalitas data ialah :

Tabel 1.1

Uji Normalitas data

\begin{tabular}{|l|c|c|c|}
\hline Siswa & Lo & Lt & Kesimpulan \\
\cline { 2 - 4 } & 0,48 & 0,116 & Normal \\
\hline
\end{tabular}


Tabel 1.2

Uji korelasi dan Signifikan Data

\begin{tabular}{|l|c|l|l|l|}
\hline Korelasi & \multicolumn{1}{|c|}{$r$} & \multicolumn{1}{|c|}{$\mathrm{t}_{\text {hitung }}$} & \multicolumn{1}{|c|}{$\mathrm{t}_{\text {tabel }}$} & keterangan \\
\hline $\mathrm{r}_{\mathrm{xy}}$ & 0,86 & 12,8 & 2,00 & Signifikan \\
\hline
\end{tabular}

Dari hasil pengujian normalitas bahwa Lo $<$ Lt maka dinyatakan Normal. Dan hasil uji korelasi diperoleh $r_{x y}$ sebesar 0,86 dengan Thitung sebesar 12,8 yang lebih besar dari Ttabel sebesar 2,00 Berdasarkan distribusi pada taraf signifikan $\alpha=0,05$ dengan $\mathrm{dk}=58$ dari $n=60$ maka korelasi antara variabel pembelajaran penjas dengan perilaku sosial siswa adalah signifikan. Sedangkan sesuai dengan interpretasi koefisien kolerasi bahwa $r_{x y}$ sebesar 0,86 maka tingkat hubungannya sangat kuat. Dengan pernyataan tersebut maka $\mathrm{H}_{0}$ ditolak dan $\mathrm{H}_{1}$ diterima oleh karena itu di dapat bahwa dalam penelitian ini adanya hubungan yang signifikan antara pembelajaran penjas dengan perilaku sosial siswa.

\section{PEMBAHASAN}

Dari pengolahan data dan analisis data di atas di dapat hasil penemuan bahwa adanya hubungan yang sangat kuat antara pembelajaran penjas dengan perilaku sosial siswa. Pernyataan tersebut sesuai dengan hasil korelasi sebesar 0,86 yang masuk dalam tingkat hubungan 0,80-1,00 sangat kuat dan uji signifikan menyatakan bahwa t-hitung $>$ t-tabel $=$ signifikan.Maka dengan adanya hubungan antara permbelajaran penjas dengan perilaku sosial siswa hal tersebut menunjukkan bahwa aspek sosial dapat menggembangkan peran yang sangat besar pada siswa dalam pembelajaran penjas. Salah satu fungsi penjas yaitu membina dan menggembangkan aspek sosial siswa dalam kehidupan di lingkungan masyarakat, , seperti menurut Kamtomo (1974, hlm. 11) bahwa dengan olahraga dapatlah dikembangkan fungsifungsi kejiwaan seseorang seperti keberanian, kepercayaan terhadap kemampuan diri, loyalitas, kecepatan proses berfikir dan sebagainya, bahkan tidak terbatas pada fungsi-fungsi kejiwaan saja, tetapi dapat pula mempengaruhi tingakah laku seseorang.

Penjelasan di atas diartikan bahwa dalam pelaksanaan pembelajaran penjas mempunyai peran yang sangat besar terhadap perubahan perilaku sosial siswa. Perilaku sosial itu dapat terbentuk dari berbagai macam kegiatan yang dilakukan oleh setiap individu dengan individu 
lain. Dimana perilaku sosial itu dapat terbentuk dengan melihat ciri dan jenis dari perilaku sosial itu sendiri, yang bisa dilihat dari individuindividu. Dan dari banyaknya kegiatan yang dilakukan, tanpa disadari bahwa apa yang dilakukan akan membentuk suatu perilaku sosial pada setiap individunya. Seperti kegiatan yang dilakukan siswa dalam mengikuti pelaksanaan pembelajaran penjas, dalam pelaksanaan pembelajaran penjas banyak aspek yang dapat dikembangkan atau dilihat diantaranya yaitu aspek kognitif, aspek psikomotor, dan aspek afektif.

Maka dari pernyataan di atas di dapat bahwa hasil penelitian ini menunjukkan hubungan antara pembelajaran penjas dengan perilaku sosial siswa, sehingga penulis berharap dengan penelitian ini dapat dijadikan masukan dan informasi lembaga pendidikan untuk lebih memperhatikan atau meningkatkan aspek sosial kepada siswa agar dapat membentuk karakter yang kuat pada setiap individunya, tidak hanya dalam pelaksanaan pembelajaran penjas saja namun dalam pembelajaran yang lainnya. Namun jika ingin lebih mudah dan lebih terlihat perilaku sosial seseorang yaitu dengan melalui pelaksanaan pembelajaran penjas karena dalam prosesnya hampir semua aspek sosial tercantum di dalamnya.

\section{KESIMPULAN}

Berdasarkan hasil pengolahan data dan analisis data penelitian ini memaparkan mengenai "hubungan antara pembelajaran penjas dengan perilaku sosial siswa". Dengan menjawab pertanyaan dari rumusan masalah serta membuktikan hipotesis penelitian, maka kesimpulannya dalam pembelajaran penjas dengan perilaku sosial siswa mempunyai hubungan yang sangat kuat, berdasarkan pada koefisien korelasi menggunakan Pearson Product Moment (PPM) sebesar 0, 86 yang diinterpretasikan pada tabel dengan $0,80-1,00$ hubungannya sangat kuat. Kemudian pembelajaran penjas dengan perilaku sosial siswa mempunyai hubungan yang signifikan, berdasarkan perhitungan statistik $\mathrm{t}_{\text {hitung }} 12,8>\mathrm{t}_{\text {tabel }} 2,00$. Dan dengan perhitungan statistik yang menandakan bahwa $t_{\text {hitung }}>\mathrm{t}_{\text {tabel }}$ maka $\mathrm{h}_{0}$ ditolak dan $\mathrm{h}_{1}$ diterima. Maka $\mathrm{h}_{1}$ yang diterimamaka untuk uji hipotesisnya ialah terdapat hubungan yang signifikan antara pembelajaran penjas dengan perilaku sosial siswa. 


\section{DAFTAR PUSTAKA}

Abidin, Saeful. 2015. Pengaruh Permainan Tradisional Terhadap Perilaku Sosial dan Kebugaran Jasmani Di SMPN 2 Megamendung. Skripsi S1 UPI-FPOK-PJKR (Skripsi)

Arikunto, Suhasismi. 2002. Prosedur Penelitian Ilmiah Suatu pendekatan Praktis. Jakarta:Rineka Cipto

Krech, Cructhfield dan Ballachey (1982) dalam Rohmah (2010) Individual in society. Tokyo: Mc Graw-Hill International Book Company.

Syamsudin, Abin. 2007. Psikologi Kependidikan. Bandung: Remaja Rosdakarya.

Rohmah, Oom. 2010. Hubungan Pembelajaran Penjas Dengan Perilaku Sosial Siswa. Bandung: Tesis Pendidikan Olahraga (Thesis)

Sugiyono. 2013. Metode Penelitian Pendidikan. Bandung: Alfabeta.

Sumber lain :

http://hobi.web.id (diakses tanggal 21 april 2016) 